\title{
Strategic Plan for Science: U.S. Geological Survey, Ohio Water Science Center, 2010-15
}

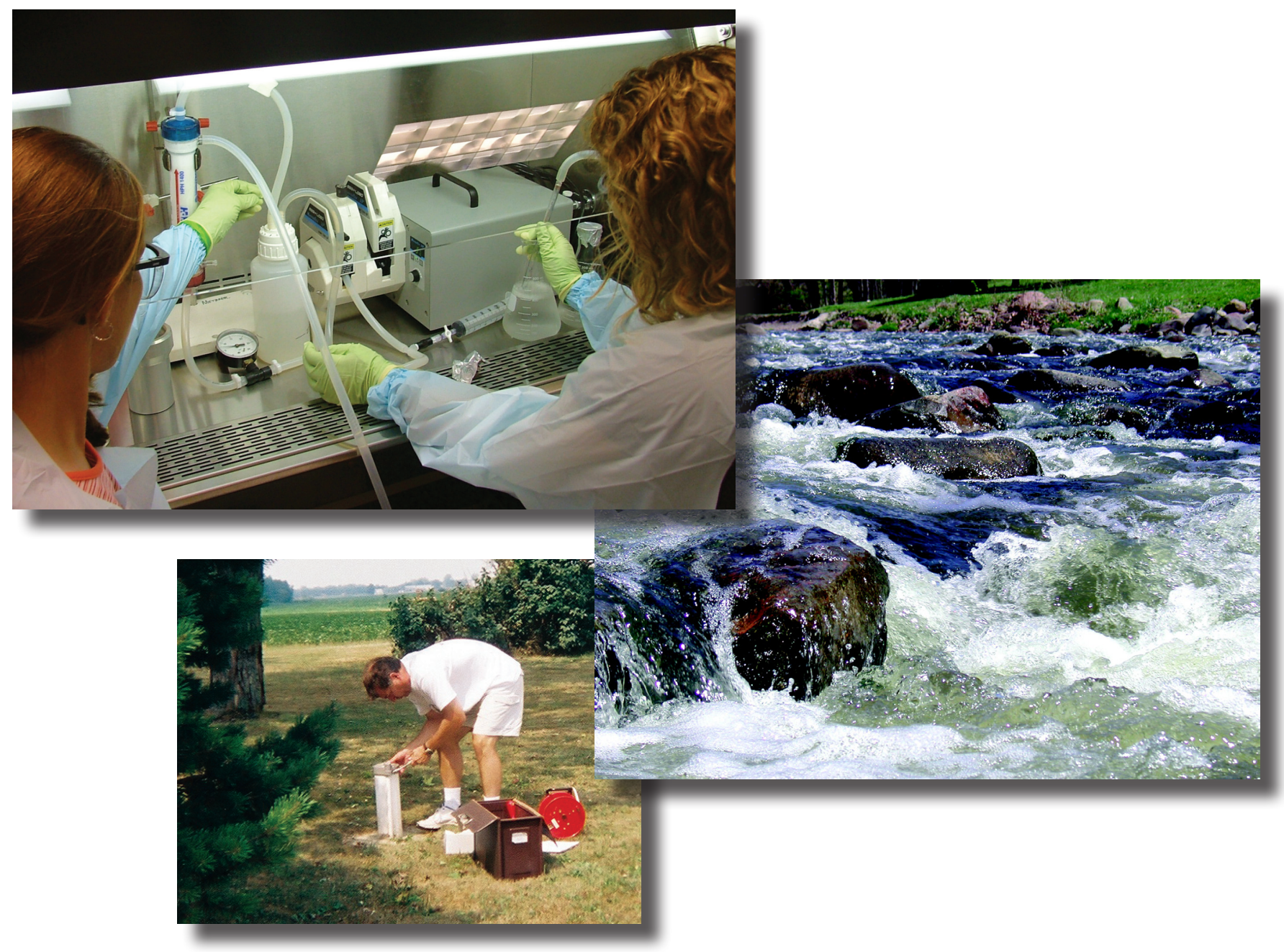

Scientific Investigations Report 2010-5156 
Cover images, clockwise from top left: (1) Ultrafiltration being done in a biosafety cabinet at the U.S. Geological Survey (USGS) Ohio Water Microbiology Laboratory; photograph by Donna Francy, USGS. (2) View of Tinkers Creek, in northeastern Ohio; photograph by John Tertuliani, USGS. (3) USGS hydrologist collecting water-well information at a site in western Ohio; photograph by Bruce Pletsch, Miami Conservancy District, reproduced with permission. 


\section{Strategic Plan for Science: U.S. Geological Survey, Ohio Water Science Center, 2010-15}

Scientific Investigations Report 2010-5156 


\title{
U.S. Department of the Interior \\ KEN SALAZAR, Secretary \\ U.S. Geological Survey \\ Marcia K. McNutt, Director
}

\section{U.S. Geological Survey, Reston, Virginia: 2010}

\author{
For more information on the USGS — the Federal source for science about the Earth, its natural and living resources, \\ natural hazards, and the environment, visit http://www.usgs.gov or call 1-888-ASK-USGS \\ For an overview of USGS information products, including maps, imagery, and publications, \\ visit http://www.usgs.gov/pubprod \\ To order this and other USGS information products, visit http://store.usgs.gov
}

\begin{abstract}
Any use of trade, product, or firm names is for descriptive purposes only and does not imply endorsement by the U.S. Government.

Although this report is in the public domain, permission must be secured from the individual copyright owners to reproduce any copyrighted materials contained within this report.
\end{abstract}

Suggested citation:

U.S. Geological Survey, 2010, Strategic plan for science-U.S. Geological Survey, Ohio Water Science Center, 2010-15: U.S. Geological Survey Scientific Investigations Report 2010-5156, 9 p. available at http://pubs.usgs.gov/sir/2010/5156/ 


\section{Contents}

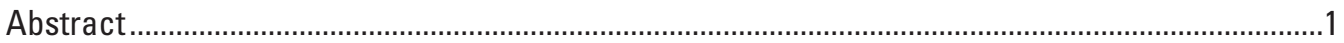

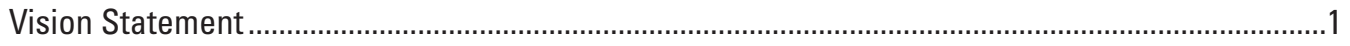

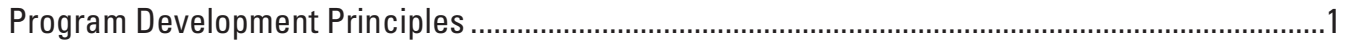

National and Regional Science Initiatives and Issues ..................................................................

USGS National Science Initiatives ......................................................................................

Science Issues of Importance in the Eastern Region ................................................................

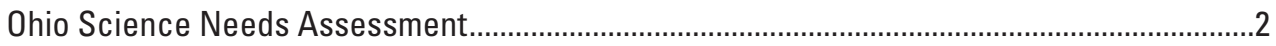

External Survey: Summary of Responses ..........................................................................

Current Water-Resource Issues...............................................................................

Emerging Water-Resource Issues ...............................................................................

Important Science Areas or Topics Not Being Addressed by USGS........................3

Impediments to Working With USGS......................................................................

USGS Influence on Decisionmaking ..................................................................... 4

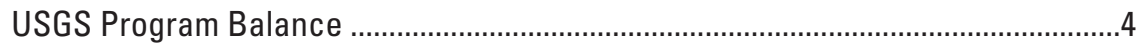

Most Relevant USGS Products................................................................................. 4

Value of USGS Products and Services.....................................................................4

Internal Survey: Summary of Important Water-Resource Issues ......................................4

Proposed Ohio WSC Science Focus Areas, Goals, and Strategies ................................................

Focus Area 1: Occurrence, Distribution, and Effects of Emerging Contaminants in Surface-Water and Groundwater Systems ................................................................ 4

Focus Area 2: Effects of Climate Change and Water Use on Water Availability, Water Quality, and Stream Biota

Focus Area 3: Identification, Tracking, Quantification, and Prediction of the Occurrence of Pathogens and Microbiological Indicators in Environmental and Treated

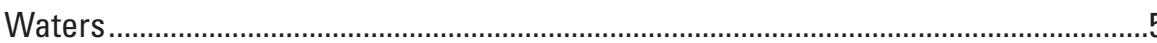

Focus Area 4: Effects of Anthropogenic Activities on the Physical, Biological, and/or Water-Quality Characteristics of Streams and/or Groundwater Systems ...................6

Focus Area 5: Operation of Hydrologic Monitoring Networks ................................................

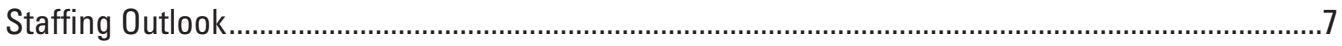

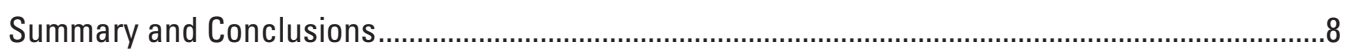

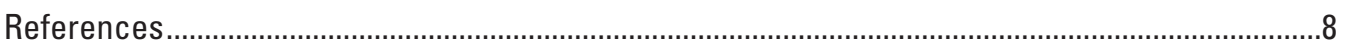

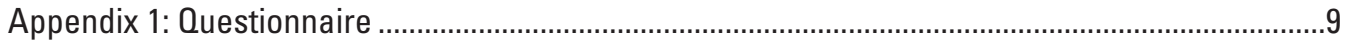




\section{Strategic Plan for Science: U.S. Geological Survey, Ohio Water Science Center, 2010-15}

\begin{abstract}
This Science Plan identifies specific scientific and technical programmatic issues of current importance to Ohio and the Nation. An examination of those issues yielded a set of five major focus areas with associated science goals and strategies that the Ohio Water Science Center will emphasize in its program during 2010-15.

A primary goal of the Science Plan is to establish a relevant multidisciplinary scientific and technical program that generates high-quality products that meet or exceed the expectations of our partners while supporting the goals and initiatives of the U.S. Geological Survey. The Science Plan will be used to set the direction of new and existing programs and will influence future training and hiring decisions by the Ohio Water Science Center.
\end{abstract}

\section{Vision Statement}

The Ohio Water Science Center (WSC) strives to be a nationally recognized leader in the water-resources community by consistently delivering high-quality hydrologic data and state-of-the science hydrologic reports to our partners and the public in a timely and efficient manner. This will be accomplished through enhanced collaboration with our partners and employees while providing a work environment where all employees have a strong sense of purpose, empowerment, and teamwork, as well as a desire to improve themselves and their products.

Inherent in meeting the intent of this vision is a continuous emphasis on the needs of our partners and the public. To maintain this emphasis, we must recognize and respond to their particular requirements and, if necessary, develop new methods or modify established methods to meet their needs.

\section{Program Development Principles}

The Ohio WSC commonly uses one of two approaches to develop program. In the first, a partner-driven approach, we identify our partners' wants and needs and develop programs and projects to address them. Some drawbacks to this approach are that partners' needs may lie outside the mission of the U.S. Geological Survey (USGS); and, in some cases, their needs largely are for data and/or basic hydrologic information that does not support cutting-edge science or research. In the second, USGS-driven approach, we attempt to guide our partners by identifying areas of potential future concern and/or suggesting specific programs or studies they may wish to undertake and support. Success with the USGSdriven approach is largely dependent on our ability to identify relevant research and the willingness of the partners to commit resources to work or research that they initially may not have perceived as an immediate need.

Historically, the Ohio WSC has followed a set of guiding principles that influence program development. Through application of these principles, Ohio WSC management and staff can best assist our partners to meet their scientific objectives. The following are the general principles that will continue to be used to facilitate program development:

Principle 1: We strive to make ourselves available to our partners (State, local, and Federal agencies or USGS program managers) as technical advisors in the planning and development of activities for their programs. Through this proactive liaison, we can better address and meet their program needs at the earliest stages.

Principle 2: Whenever possible, we use data from our existing databases and networks, supplementing with new monitoring only when the need arises. By exploiting already procured data, we reinforce to our partners the utility and value of our existing networks and databases, as well as minimize additional expenditures.

Principle 3: We reorient or repurpose existing data networks, where it is technically sound to do so, to collect the data necessary to support partner science needs. Again, this principle reinforces to our partners the utility and value of our existing networks, as well as minimizes additional expenditures.

Principle 4: We strive to develop interpretive studies that produce accurate, unbiased, and timely results that are conveyed in understandable and useful formats. Depending on the nature of the study, results may be distributed in a variety of forms including journal articles, printed reports, fact sheets, Web-based media, databases, software, or public meetings. 


\section{National and Regional Science Initiatives and Issues}

The USGS identified a strategic science direction to articulate areas where USGS science could be used to address critical societal issues that are important to the Nation. To the extent possible, the Ohio WSC science strategy will promote and support these issues and initiatives.

\section{USGS National Science Initiatives}

The USGS science strategy (U.S. Geological Survey, 2007) outlines the major natural-science issues facing the Nation in the next decade and consists of the six science initiatives described below:

1. Understanding ecosystems and predicting ecosystem change.-Ensuring the nation's economic and environmental future.

2. Climate variability and change.-Clarifying the record and assessing consequences.

3. Energy and minerals for America's future.-Providing a scientific foundation for resource security, environmental health, economic vitality, and land management.

4. A national hazards, risk, and resilience assessment program.-Ensuring the long-term health and wealth of the Nation.

5. The role of environment and wildlife in human health.-A system that identifies environmental risk to public health in America.

6. A water census of the United States.-Quantifying, forecasting, and securing freshwater for America's future.

\section{Science Issues of Importance in the Eastern Region}

The USGS Eastern Region's Science Plan (U.S. Geological Survey, 2004) lists the following four major societal issues and identified categories of USGS science that address those issues:

1. Urban Dynamics

- Water quality and availability for humans and ecosystems

- Habitat fragmentation

- River and coastal processes

- Urban expansion and landscape change
2. Ecosystem and Natural Resources

- Climate change

- Fish and wildlife health

- Eutrophication and hypoxia

- Biodiversity, habitat integrity and restoration

- Invasive and nuisance species

- Energy and mineral-resource extraction

3. Human Health and Safety

- Arsenic contamination

- Mercury bioaccumulation

- Trace elements and radionuclides

- Synthetic and natural organic contaminants (emerging contaminants)

- Pathogens and disease

- Air quality

4. Natural Hazards

- Flooding, storms, and drought

- Earthquakes

- Slope failure and subsidence

\section{Ohio Science Needs Assessment}

External and internal surveys were done to help assess Ohio's science needs. External surveys consisted of a written questionnaire sent to agency personnel who partner or otherwise collaborate (or have the potential to collaborate) with the USGS Ohio Water Science Center; in some cases, the mailing of the questionnaire was followed by in-person or telephone interviews. The written questionnaire (appendix 1) sought information about the agencies' current and emerging waterresource issues, important issues that are not being addressed by USGS, impediments to working with USGS, USGS influence on their decisionmaking processes, USGS program balance, most relevant USGS products, and the perceived value of USGS products and services. Internal surveys consisted of brainstorming sessions during which Ohio WSC personnel identified and discussed issues and areas that they felt should be prioritized for additional study.

Results from the external and internal surveys were considered in development of the Science Plan, along with national and regional initiatives and issues. Logically, topics that are deemed important at multiple scales (national, regional, and/or local) were given extra consideration and addressed in the Science Plan. 


\section{External Survey: Summary of Responses}

\section{Current Water-Resource Issues}

- Source water protection.-Identifying sources of microbial groundwater contamination.

- Emerging contaminants.-Understanding the severity and impacts of known contaminants (for example, emerging contaminants and C-8).

- Harmful algal blooms. - Gaining a better understanding of the cause and impacts of blooms in lakes and reservoirs.

- Water use and availability.-Answering the question, "Do we (and will we) have enough water, and what is a 'reasonable' use?"

- Water security.-Indentifying potential impacts of intentional or unintentional contamination.

- Gage network.-Maintaining adequacy for regional statistics, flood warning/assessment, and science support.

- Stormwater management and Phase II stormwater regulations.-Providing guidance.

- Effects of dam removal.-Determining potential impacts of site-specific dam removals.

- Nitrates in waters. - Collecting and synthesizing data to support regulation.

\section{Emerging Water-Resource Issues}

- Developing chemical/biological tools to characterize the health of streams affected by acid mine drainage (AMD).

- Understanding the effect of longwall mining on stream recharge and discharge.

- Developing a better understanding of the distribution and occurrence of algal toxins in surface waters and their causative factors.

- Better characterizing mussel populations and their relation to water quality.

- Better understanding the significance of emerging contaminants from a health and regulatory standpoint.

- Developing and validating aquatic-pathogen identification methods for assessing water security.
- Better characterizing the occurrence and concentrations of biological agents (for example, pathogens) in drinking-water sources.

- Understanding/characterizing the potential effects of climate change on flood hydrology.

- Better understanding the effects of runoff-reducing best management practices (BMPs) on flood hydrology and water quality.

- Better characterizing the impacts of predicted flood magnitudes on communities and transportation arteries.

- Improving the understanding of highway runoff on groundwater quality.

Important Science Areas or Topics Not Being Addressed by USGS

- Assistance in developing Acid Mine Drainage Abatement and Treatment plans.

- Research and information on low-volume sampling for PCBs.

- Research and information on antibiotics, hormones, and pathogenic organisms associated with confined animal feeding operations.

- Research into the efficacy of high-rate wastewater treatment.

- Methods for helping to visualize what a "No Adverse Impact" approach to water-resources management could look like.

- Education of local flood-plain managers on hydrology and hydraulics as they relate to flood-plain regulation.

- Research into effects of channel modifications (for example, two-stage ditches) on water quality.

- Research into identifying and understanding matrix effects that inhibit or interfere with detections of microorganisms.

- Research and information on the microbial flora making up biofilms in wells and distribution systems.

Impediments to Working With USGS

- No funds or limited funds for the partner agency.

- Universities' desire to maintain intellectual property rights to work. 


\section{USGS Influence on Decisionmaking}

- Agencies make use of real-time data and StreamStats to make operational decisions.

- One agency expressed interest in learning more about rapid methods for enumeration of bacteria and about qPCR technologies to aid decisionmaking.

- Agencies reported use of other selected USGS products and reports in their decisionmaking processes.

\section{USGS Program Balance}

- Agencies either felt the balance was about right or had no opinion.

\section{Most Relevant USGS Products}

- Real-time and other gaging data.

- StreamStats.

- Flood-insurance studies.

- Sampling methods and protocols.

- Digital spatial data.

Value of USGS Products and Services

- Those agencies who had worked with USGS felt that USGS services were fairly priced.

- One agency qualified the comment above to say that it applied mostly when information of the highest quality was desired.

\section{Internal Survey: Summary of Important Water- Resource Issues}

- Effects of agricultural practices (for example, chemical use, animal husbandry, planting practices) on water quality and aquatic biota.

- Effects of climate change and/or other factors (for example, land use) on water availability and quality.

- Effects of mining (of various types) on water quality and aquatic biota.

- Methods development for tracking, identification, and/ or prediction of microbial contaminants in water.

- Source-water vulnerability due to natural and/or human-influenced contaminants.
- Occurrence, distribution, and effects of emerging contaminants in surface water and groundwater.

- Development and use of water-quality indicators.

- Relation of nutrients to eutrophication and/or algal blooms in lakes, and identification of nutrient sources.

- Effects of changes in water availability and/or streamflow dynamics on aquatic, riparian, and/or human populations.

- Data and methods to support and improve flood warning.

- Assessment of physical, biological, and/or waterquality effects of BMPs and/or stream rehabilitation efforts (for example, low-impact development, channel modifications, dam removal, and so forth).

\section{Proposed Ohio WSC Science Focus Areas, Goals, and Strategies}

\section{Focus Area 1: Occurrence, Distribution, and Effects of Emerging Contaminants in Surface- Water and Groundwater Systems}

\section{Background}

A variety of chemicals that are used everyday in homes, industry, and agriculture enter our streams and groundwater. Some of these chemicals are referred to as "emerging contaminants" because their widespread presence in water and potential effects on aquatic and human health are of emerging concern; they include compounds such as human and veterinary drugs, hormones, detergents, disinfectants, plasticizers, fire retardants, insecticides, and fragrances. Local and national studies have shown that emerging contaminants commonly occur in complex mixtures in surface-water and groundwater systems, and resultant negative health effects have been documented in some aquatic communities. Furthermore, conventional systems for producing potable water do not completely remove some of these contaminants, resulting in the potential for chronic low-level exposure in humans.

\section{Goals}

- Better understand the occurrence and distribution of emerging contaminants in Ohio's surface-water and groundwater resources.

- Begin to develop an understanding of the ecological significance of observed concentrations, as well as implications for water supplies and water suppliers. 


\section{Strategies}

- Increase staff exposure to scientific literature and news reports with the idea of remaining current on issues related to emerging contaminants (for example, human toxicity, endocrine disruption, interaction with engineered nanoparticles, and so forth), their movement in the environment, and their relative importance to society.

- Pursue additional studies on emerging contaminants with municipalities, water suppliers, and/or State health agencies so that more can be learned about the types, amounts, pathways, and distribution of emerging contaminants in the State's waters.

- Pursue and evaluate new technologies for measuring emerging-contaminant concentrations and/or their effects on aquatic populations.

- Build technical associations with regulatory-agency and water-resource program managers, USGS and other government-agency researchers, and research groups at Ohio institutions of higher learning involved in studies of contaminant transport and effects.

\section{Focus Area 2: Effects of Climate Change and Water Use on Water Availability, Water Quality, and Stream Biota}

\section{Background}

Water is a vital resource whose availability for use by human and aquatic populations is a function of both its quantity and its quality. Human activities can affect water availability through a variety of ways including contamination of surface-water and/or groundwater sources, excessive withdrawals, and climate change induced by extensive deforestation and/or excessive production of greenhouse gases. More information is needed on the factors potentially affecting water availability and quality and the attendant implications for human and aquatic uses.

\section{Goals}

- Develop or improve our ability to assess and/or model the effects of various amounts of water use and/or climate change on the quantity and/or quality of surfacewater and groundwater resources.

- Develop an improved understanding of the ecological implications of changes in the timing, variability, and/or total amount of water available in streams and aquifers.

\section{Strategies}

- Increase staff exposure to scientific literature and news reports related to current theories about climate change and its potential impacts on hydrologic systems.

- Improve existing methods or develop new methods to track and utilize information on water uses in order to better understand water-use impacts on surface-water and/or groundwater systems.

- Improve our understanding of instream flows required to support healthy aquatic biota in Ohio streams.

- Improve our ability to model hydrologic and waterquality processes in a fashion that supports evaluation of alternative water-use and/or climate-change scenarios.

- Pursue modeling studies aimed at evaluating the potential impacts of expected water-use or climate-change scenarios.

- Develop expertise with the coupled Groundwater and Surface-water FLOW (GSFLOW) model.

\section{Focus Area 3: Identification, Tracking, Quantification, and Prediction of the Occurrence of Pathogens and Microbiological Indicators in Environmental and Treated Waters}

\section{Background}

Pathogens enter our waters in runoff and/or discharges containing untreated or partially treated wastes or wastewaters. Health risks to humans and aquatic populations can result from ingestion of, or contact with, fecally contaminated water. Methodologies and tools are needed to rapidly identify, track, quantify, and/or predict the occurrence of pathogens in water so that we can minimize the risk of exposure to pathogens and can identify and remediate important fecal contaminant sources.

\section{Goals}

- Continue to advance our ability to identify, enumerate, and track bacterial indicators and pathogens in water by developing and applying new and improved microbiological methods such as quantitative polymerase chain reaction (qPCR) and immunomagnetic separation (IMS)/adenosine triphosphate (ATP), as well as use of host-specific DNA markers.

- Continue to explore and improve techniques for accurately predicting when coastal and inland recreational waters are likely to have bacterial concentrations that exceed recreational water-quality standards. 


\section{Strategies}

- Improve and test techniques and capabilities with respect to identification and enumeration of bacterial indicators and pathogenic bacteria, viruses, and protozoa.

- Continue to refine and improve rapid analytical methods, such as IMS/ATP and qPCR.

- Continue to pursue and refine methods for identifying and enumerating sources of fecal contamination in lakes, streams, and aquifers by applying the use of host-specific markers and other source-tracking techniques.

- Continue to evaluate and refine predictive models for estimating bacteria concentrations in rivers and at beaches and pursue new and better ways to disseminate model results (for example, by using the Internet, social-networking software, text messaging, and so forth).

- Build technical associations with regulatory-agency and water-resource program managers, USGS and other government-agency researchers, and research groups at national and international institutions of higher learning involved in relevant microbiological studies.

\section{Focus Area 4: Effects of Anthropogenic Activities on the Physical, Biological, and/or Water-Quality Characteristics of Streams and/or Groundwater Systems}

\section{Background}

Of all of the species on Earth, humans are unique in that they extensively modify their environment to suit their needs. Practices such as agriculture, mining, and development can dramatically change the natural landscape, which, in turn, can significantly affect patterns, quantities, and quality of runoff. In some cases, modifications are made directly to stream channels to create instream storage, expedite the removal of floodwaters, minimize overbank flooding, or to stabilize and/or remediate channels that are perceived to be unstable or subject to excessive erosion. In other cases, engineering solutions are employed outside of the stream channel to control runoff and/ or improve its quality. In many cases, the short- and long-term consequences and efficacy of those modifications are either unknown or poorly understood.
Goals

- Improve our understanding of the effects of anthropogenic activities on the physical, biological, and/or water-quality characteristics of streams and/or groundwater systems and expand our ability to model and predict the physical, biological, and/or water-quality impact of existing or proposed activities or remediation efforts.

\section{Strategies}

- Develop increased expertise and use of geophysical and geomorphological techniques.

- Develop increased expertise and use of tracer technologies for both surface-water and groundwater systems.

- Develop methods suitable for assessing the potential impacts of dam construction, dam removal, and stormwater best-management practices on streams and aquatic biota.

- Develop increased expertise in eutrophication processes and algal population dynamics.

- Expand surface-water, groundwater, and water-quality modeling capabilities. In particular, increase expertise in the use of HSPF for surface-water and water-quality modeling, and become familiar with the sedimenttransport and moveable-bed modeling capabilities of HEC-RAS; optimization modeling with MODFLOW; groundwater/surface-water modeling with GSFLOW; and solute-transport modeling with HST3D and SUTRA.

- Expand expertise in environmental inorganic and organic chemistry and biogeochemistry.

- Increase understanding of aquatic-ecosystem health by enhancing technical associations with regulatoryagency program managers, government-agency researchers, and other research groups.

- Develop experience with two- or three-dimensional hydrodynamic and water-quality-modeling techniques. Specific models of interest include RMA2, RMA4, MD_SWMS, SRH-2D, RMA10 and U2RANS. 


\section{Focus Area 5: Operation of Hydrologic Monitoring Networks}

\section{Background}

The U.S. Geological Survey has the principal responsibility within the Federal Government to provide the hydrologic information and understanding needed by others to achieve the best use and management of the Nation's water resources. Hydrologic monitoring networks provide a foundation for meeting that responsibility. Among other things, hydrologic monitoring networks (1) facilitate the determination regional aquifer and streamflow statistics, (2) provide timely information that is used by planners and emergency personnel to assess and respond to floods and droughts, and (3) provide data that support a variety of surface-water and groundwater hydrologic assessments and research.

\section{Goals}

- Maintain and/or expand the hydrologic monitoring network so that we can collect the necessary data to provide relevant and accurate regional information on aquifer and streamflow characteristics.

- Explore ways to reduce network maintenance costs, improve data reliability, and provide fast and efficient mechanisms for disseminating data in useful formats to our partners and the public.

\section{Strategies}

- Actively promote the expansion of the statewide cooperative streamgage network to monitor stage, streamflow, and water quality.

- Maintain and enhance our ability to deliver real-time hydrologic information in a nationally consistent and organized manner.

- Pursue new and better ways to disseminate real-time hydrologic information (for example, by means of the Internet, social-networking software, text messaging, and so forth).

- Maintain the existing USGS corporate hydrologic database - the National Water Information System (NWIS and NWISWeb) and continue to quality-assure historical data and computed values.

- Maintain and improve the Ohio StreamStats application to facilitate estimation and/or dissemination of site-specific streamflow statistics.
- Increase technical associations with government agencies and research groups to promote the scientific understanding of the relation between environmental and climatic conditions and to raise awareness about water-resources management issues.

- Through training and experience, maintain and enhance the expertise of our hydrologists, engineers, and hydrographers in collecting and analyzing surfacewater and groundwater data.

- Encourage USGS technical support staff to continue the enhancement and development of standard analytical tools available to evaluate hydrologic extremes, estimate traveltimes and recession rates, predict the probable depths and timing of flood peaks, and statistically analyze streamflows and groundwater levels.

- Pursue opportunities and strategies to facilitate floodhazard warning and monitoring.

- Maintain readiness and expertise to support postflood assessments of water-surface profiles and peak flows.

- Increase use of, and expertise with, acoustic-based streamflow-measurement equipment to facilitate rapid and accurate streamflow measurements, thereby improving efficiency and productivity.

- Adopt and become proficient with tools and software (for example, PDA-based leveling software, GR-SAT, SWAMI, CHIMP) that improving efficiency and productivity in general gaging-station operations and records computation.

\section{Staffing Outlook}

The current scientific and technical staff of the Ohio WSC has the skills needed for the successful implementation of the Science Plan. Continued training and strategic future hires in specific technical areas will enhance the current staff skills. The WSC staff can and will be supplemented with USGS staff from the Biology, Geography, Geology, and/or Geospatial Discipline centers and other WSCs, as needed, to conduct multidisciplinary and regional studies. Additionally, when appropriate, WSC staff will collaborate with scientists and water managers from other agencies, as well as academia and the private sector, to meet the objectives of the Science Plan. 


\section{Summary and Conclusions}

The U.S. Geological Survey, Ohio Water Science Center (WSC), conducted internal and external surveys to help assess current science issues of importance to Ohio and the Nation. Results of those surveys, along with information on nationally and regionally significant strategic science issues, were used to develop a science plan featuring five topical focus areas with associated science goals and potential strategies for meeting those goals. The five topical focus areas are the following:

1. Occurrence, distribution, and effects of emerging contaminants in surface-water and groundwater systems.

2. Effects of climate change and water use on water availability, water quality, and stream biota.

3. Identification, tracking, quantification, and prediction of the occurrence of pathogens and microbiological indicators in environmental and treated waters.

4. Effects of anthropogenic activities on the physical, biological, and/or water-quality characteristics of streams and/or groundwater systems.

5. Operation of hydrologic monitoring networks.

The Science Plan will be used to set the direction of new and existing programs and will influence future training and hiring decisions by the USGS Ohio Water Science Center.

\section{References}

U.S. Geological Survey, 2007, Facing tomorrow's challengesU.S. Geological Survey science in the decade 2007-2017: U.S. Geological Survey Circular 1309, 69 p., accessed August 21, 2009, at http://pubs.usgs.gov/circ/2007/1309/ pdf/C1309.pdf.

U.S. Geological Survey, 2004, Eastern Region Science Plan: Internal document, 34 p., accessed August 21, 2009, at http://internal.er.usgs.gov/docs/er_science_planver8-01-20-04.doc. 


\section{Appendix 1: Questionnaire}

Cooperator:

Date of Interview:

Person(s) Interviewed:

Conducted by:

Preface:

The U.S. Geological Survey's Ohio Water Science Center (OH WSC) is currently developing its new Strategic Science Plan. Through this process, the OH WSC hopes to identify specific scientific and technical water-resource programmatic areas and issues important to Ohio and the Nation.

The primary goal of the OH WSC Science Plan is to establish a multidisciplinary scientific and technical program that generates relevant scientific products that meet or exceed our cooperator needs while supporting the goals and initiatives of USGS. The Science Plan will be used to set the direction of new programs in the $\mathrm{OH}$ WSC and be used in future training and hiring decisions.

We value your organization's input and perspective as we go through this process. We thank you for agreeing to participate in this "look forward" to help us assess and define the major issues that will be relevant to Ohio water-resource professionals and decision makers in the next five years.

Before answering the following eight questions you may want to consider the following major water-resource perspectives:

- Regulatory Issues

- Recreation Needs

- Data Needs and Gaps

- Environmental Quality and Human Health

- Water Availability and Sustainability

- Hydrologic Systems, Surveillance, and Hazards

1) What are the most important water-resource issues facing your organization within the next one- to twoyear period?

2) What water-resource issues (needs) do you foresee emerging in Ohio and the Nation relevant to your organization's mission/responsibilities within the next five-year period and beyond?

3) Please identify any areas of water-resource science that the OH WSC is not addressing, but should be addressing.
4) Please identify any issues (e.g., science, regulatory, fiscal, and procedural) that might prevent your organization from cooperating with the $\mathrm{OH}$ WSC in the future.

5) How do OH WSC products and/or expertise influence decisionmaking in your organization?

6) The Ohio WSC conducts basic water-resource monitoring and interpretive research (approximately $55 \%$ and $45 \%$ of our program, respectively). Do you perceive this program balance to be about right?

7) What $\mathrm{OH}$ WSC products or services are the most relevant to your organization?

8) Do you believe the value and cost of OH WSC products or services are commensurate? 
吕

.

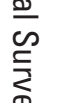

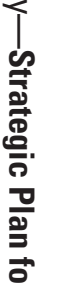

D.

.

号

음.

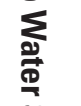

s

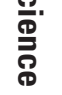

罡

$\tilde{O}$
Oे
ज़
i

م.

鲟

言:

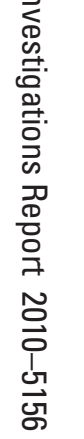

